\title{
Fighting the SARS CoV-2 (COVID-19) pandemic with soap
}

\author{
Narendra Kumar Chaudhary ${ }^{1}$, Nabina Chaudhary ${ }^{2}$, Manish Dahal ${ }^{3}$, Biswash Guragain ${ }^{1}$, \\ Summi Rai ${ }^{1}$, Rahul Chaudhary ${ }^{2}, \mathrm{KM} \mathrm{Sachin}^{4}$, Reena Lamichhane-Khadka ${ }^{5}$ and Ajaya \\ Bhattarai $^{1 *}$ \\ 1 Department of Chemistry, Mahendra Morang Adarsh Multiple Campus, Biratnagar, (Tribhuvan \\ University) Nepal \\ 2 Dhaka Central International Medical College, Dhaka University, Bangladesh \\ 3 Department of Microbiology, Birat Multiple College, Biratnagar, (Tribhuvan University) Nepal \\ 4 School of Chemical Sciences, Central University of Gujrat, Gandhinagar, India \\ 5 Department of Biology, Saint Mary's College, Notre Dame, Indiana, USA \\ *Correspondence: bkajaya@yahoo.com, ajaya.bhattarai@mmamc.tu.edu.np; Tel.: +977- \\ 9842077434
}

\begin{abstract}
:
The greatest pandemic of the century, COVID-19, is an ongoing global public health problem. With a clinically approved treatment available only for those who are acutely ill and are hospitalized, the control of this disease in the general population is still largely dependent on the preventive measures issued by the World Health Organization. Among the general control measures other than immunization with the COVID-19 vaccines, handwashing with soap and water has been emphasized the most because it is cost-effective and easily accessible to the general public. Studies have reported that soaps offer unique chemical properties that can completely destroy enveloped viruses. However, the general public seems to be still uncertain about whether soaps can shield us from a highly contagious disease such as COVID-19. In an attempt to help eliminate the uncertainty, we analyzed the mechanisms underlying the efficacy of soap and its prospect for preventing the spread of COVID-19. In this paper, we provide an overview of the history and characteristics of the SARS-CoV-2 virus, the current global COVID-19 situation, the possible mechanisms of the deactivation of viruses by soaps, and the potential effectiveness of soap in eliminating coronaviruses including SARS-CoV-2.
\end{abstract}

Keywords: COVID-19; SARS-CoV-2; Soap; Handwashing; WHO

\section{Introduction}

While the entire world was bidding farewell to 2019 and welcoming the New Year 2020, health officials in Wuhan, the capital city of Hubei Province in China, were dealing with an unprecedented number of unusual cases of severe pneumonia. Later, the cases were known to be caused by a novel coronavirus [1]. The virus continued to spread at an unprecedented rate, crossing all geographical boundaries, and it continued to spread the infection to almost all nations around the world. In about three months, it spread to 210 nations worldwide. Considering the extent of the threat to global public health, the World Health Organization (WHO) officially declared it a pandemic on $11^{\text {th }}$ March 2020 [2,3]. COVID-19 is now recorded as the deadliest infectious disease of the decade in history [4]. 
As of May 2020, no clinically approved vaccine or antiviral agents against coronaviruses had been discovered [5]. The clinical treatment procedure was under trial. This, together with the observation that the highly contagious severe acute respiratory syndrome coronavirus 2 (SARS-CoV-2) could spread at unprecedented rates, caused massive psychological effects on the public, and public health agencies struggled to keep their confidence to mentally strengthen people [6]. In this context, public health actions has been crucial in slowing the spread of COVID-19 [7]. Based on earlier research works and practices, the WHO issued frequent washing of hands with soap and water as a precautionary measure to reduce the possible spread of the virus. Furthermore, the use of masks, disinfectants, and alcohol-based hand sanitizers (ABHS) is highly recommended [8,9], and strict maintenance of social distancing and enhanced personal hygiene has been suggested $[7,10]$.

Previous research on coronavirus outbreaks has primarily focused on the epidemiology and clinical characteristics of infected patients, the genomic characterization of the virus, and identifying the challenges for global health governance. However, there have been no studies on the effectiveness of handwashing with soap-water against the transmission of coronavirus. In this article, we provide a detailed review of the history, characteristics and emergence of the SARS-CoV-2 virus, the current global COVID-19 situation and control measures, the possible mechanisms of disinfection by soap, and the potential effectiveness of soap in reducing the spread of coronaviruses including SARS-CoV-2. The referenced literature for this study was systematically reviewed and searched in PubMed, Google Scholar, and various academic and research publication websites. We did not set year limit for this search. A manual search was also performed to collect appropriate literature. This search was conducted based on title, author name, and journal scope. Since the COVID-19 outbreak is continuously evolving, the reported information was conducted based on real-time analysis. The compositional aspects of soap and its chemistry for the deactivation of the virus were collected from different journal sources.

\section{History, characteristics, and evolution of SARS-CoV-2}

\subsection{Taxonomy, structure, and morphology}

The name "coronavirus," was coined by Tyrell and co-workers in 1968 [11,12]. It is derived from the Latin word corona (meaning crown) for its crown-like morphology when observed under an electron microscope. The coronavirus $(\mathrm{CoV})$ belongs to the Coronaviridae family in the order Nidovirales, further sub-classified into four genera: Alpha-CoV, Beta-CoV, Gamma$\mathrm{CoV}$, and Delta-CoV [10]. Among these, Alpha-CoV and Beta-CoV consist of human pathogenic coronaviruses (HCoV) [1]. In January 2020, the World Health Organization (WHO) temporarily named it a 2019 novel coronavirus [13]. Considering the high (almost 86\%) genomic similarity of this virus with the SARS-CoV [14], the International Committee on Taxonomy of Viruses (ICTV) named the novel coronavirusSARS-CoV-2, and the disease caused by this virus as the COVID-19, on $11^{\text {th }}$ February 2020 [3].

Coronaviruses are round enveloped viruses, approximately $65-125 \mathrm{~nm}$ in diameter. They are RNA viruses. Each virus contains a single positive-strand RNA (+ssRNA) that ranges in size from 26-30 kilobases, the largest RNA genome known to date [1]. The genome is complexed with the nucleocapsid $(\mathrm{N})$ protein to form a helical capsid enveloped within the lipid (bilayer) membrane [15]. Embedded into the membrane are at least three viral proteins: the spike (S) glycoprotein that forms the peplomers on the virion surface, giving the virus its crown-like morphology; the membrane (M) protein, the most abundant structural protein, and the envelope 
101

102

103

104

105

106

107

108

109

110

111

112

113

114

115

116

117

118

119

120

121

122

123

124

125

126

127

128

129

130

131

132

133

134

135

136

137

138

139

140

141

142

143

144

(E) protein, the small hydrophobic protein. Some coronaviruses also have an additional membrane protein called hemagglutinin esterase (HE) [16]. The S glycoprotein mediates attachment of the virus to the host cell surface receptors with the subsequent fusion between the virion and host cell membranes, facilitating its entry into the host cell. The M protein and the E protein on the viral surface together define the shape of the viral envelope [17] (Figure 1).
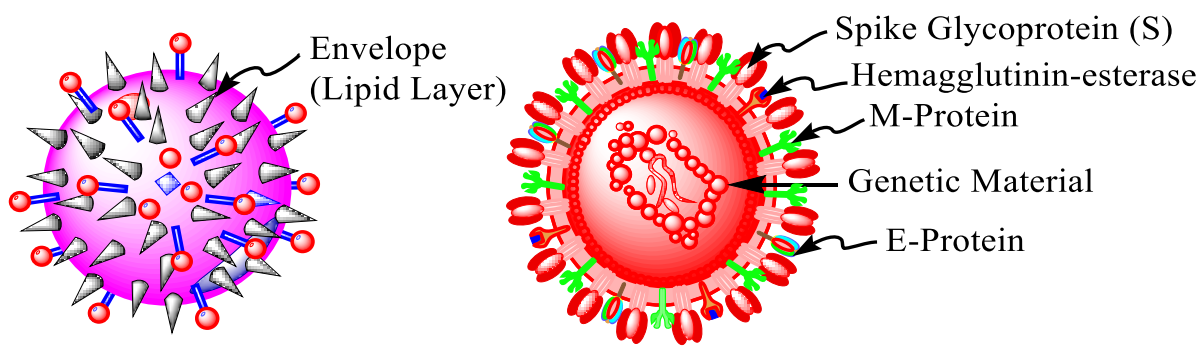

Figure1. A) 3D structure of SARS-CoV-2

B) Internal structure of the virus

The lipid bilayer enveloped around the virus plays a major role in both infecting the host cell and in inactivating the virus as a whole. It is simply an outer protective layer on the virus made up of fat molecules (phospholipids) that protect the virus when it is outside the host cell. The fat molecules making up the bilayer are amphiphilic with a hydrophilic (phosphate) head covalently bonded to a hydrophobic (lipid) tail. These fatty molecules arrange themselves into a double layer piled on top of each other into a sheet with tails pointing inwards and heads pointing outwards, covering the genome of the virus. The lipid layer also enables the virus to attach to the host cell surfaces, thereby initiating the infection [18].

\subsection{Transmission and replication}

Like every other respiratory virus, SARS-CoV-2 spreads to humans when exposed to contaminated respiratory droplets produced by an infected person when they sneeze, cough, and even respire [19]. Inanimate objects and surfaces exposed to such respiratory droplets can become potentially infectious fomites and can easily transfer the virus even after hours of contamination [20]. The deposition of infected droplets or aerosols on the respiratory mucosal epithelium probably initiates viral infection. The most crucial step in viral infection is the fusion between the viral and host cell membranes. The virus binds itself through its spike proteins (S) with the cell surface receptors ACE-2 (Angiotensin Converting Enzyme-2) and TMPRSS-2 (transmembrane protease serine 2) and enters the host cell via endocytosis. Within the host cell, the virus uncoats and releases its +ssRNA. The +ssRNA binds to the cytosolic ribosome or the ribosome on the rough endoplasmic reticulum. Once these + ssRNAs move through the cytosolic ribosome, they are translated into proteins called polyproteins, which are utilized for making spike protein(S), membrane protein $(\mathrm{M})$, an envelope protein (E), and nucleocapsid protein $(\mathrm{N})$. Polyproteins also synthesize an enzyme called RNA-dependent RNA polymerase, which makes more copies of +ssRNA, resulting in the formation of a large number of polyproteins and structural proteins. The +ssRNA molecules combine with the S, M, E, and $\mathrm{N}$ proteins and are transported to the Golgi apparatus where they are packed into vesicles and eventually re-assembled into new virus particles surrounded by the lipid bilayer. Finally, the lipid bilayer fuses with the host's cell membrane, and the viruses exit the host cell via exocytosis [21].

\subsection{Clinical manifestations}


COVID-19 manifests with a wide range of clinical symptoms, ranging from the mild common cold to severe pneumonia [22]. In general, it is characterized by common symptoms such as high fever, dry cough, tiredness, and other symptoms including aches, nasal congestion, running nose, sore throat, and diarrhea [10]. Some individuals may also experience trouble breathing, persistent pain or pressure in the chest, new confusion or inability to arouse, bluish lips, or face [23].

\subsection{Emergence and spread of SARS-CoV-2}

Though the particular coronavirus causing the "COVID-19" pandemic is novel, coronaviruses (CoVs) in general are not new pathogens; they were discovered in the early 1930s as the causative agent of a severe respiratory infection in domesticated chickens, and are now known as avian infectious bronchitis virus (IBV). The first human coronavirus (HCoV) was discovered in the 1960s, but it remained relatively obscured for years [24,25], probably because no severe human disease (only mild common cold) was caused by it. In 2003, a new variant of the coronavirus (named SARS-CoV) emerged in Southern China and caused epidemics of the severe acute respiratory syndrome (SARS) in multiple countries. Consequently, in 2012, another new variant, the Middle Eastern Respiratory Syndrome coronavirus (MERS-CoV) appeared in Saudi Arabia and spread across continents [26]. The emergence of SARS-CoV and MERS-CoV and the impact that these viruses posed on human health led the coronaviruses to be recognized as viruses of significant threat to human health [17].

Since the onset of the COVID-19 pandemic in late 2019, it has significantly impacted the health, education, and economic sectors on a global scale. The COVID-19 outbreak hit Europe hard, starting in Italy in February 2020, and later made the continent a global epicenter of the disease by late March and April 2020 [27]. During that time, Italy faced the highest COVID-19 fatality rate in the world. A month later, the country faced another wave of uncontrolled COVID-19 outbreak [28]. From the third week of March 2020, the South American countries faced an unprecedented increase in COVID-19 cases causing enormous pressure on their health systems [29]. As of July 5, 2021, a total of 184,573,518 confirmed cases, 3,993,602 deaths, and 168,922,458 recovered cases worldwide have been recorded.

The United States of America has registered the highest number of confirmed cases $(34,275,783$ cases) followed by India with $29,274,823$ registered cases. Other ten most infected countries include Brazil $(17,215,159)$, France $(5,729,967)$, Turkey $(5,313,098)$ Russia $(5,180,454)$, United Kingdom $(4,542,986)$, Italy $(4,239,868)$, Argentina $(4,066,156)$, Spain $(3,729,458)$, Germany $(3,718,617)$, and Colombia $(3,665,137)[30]$.

Since the emergence of COVID-19, health intelligence has been trying to analyze the SARSCoV-2 genome to understand the evolution of this virus. This has been challenging, mainly due to the rapidly changing genome of the virus resulting in new variants [31]. Since SARSCoV-2 is an RNA virus, it has a high rate of genomic mutation. Several mutations have been identified in the spike proteins, among which the most predominant one is the D614G mutation which efficiently reduces $S 1$ shedding and increases viral infectivity [32,33]. A new variant (B.1.1.7) was first identified in September 2020 in the United Kingdom with an exceptionally large number of mutations, unprecedented spreading ability, and rapidly evolving epidemiologic potential. Over 90 countries, including the United States, have registered cases of the B.1.1.7 variant since December 20, 2020. Another variant (B.1.351) was identified at the beginning of October 2020 in South Africa irrespective of the variant observed in the UK. 
195 [34]. This new strain shared some mutations with the variant observed in the UK. Recently,

196 Nigeria has also reported the existence of the new variant. However, no evidence leads to cursory disease or an elevated risk of death associated with these new variants [35]. The new variant of SARS-CoV-2 in the UK has created such a harsh situation that the government imposed even stricter restrictions on every sector to control its spread [36]. The P.1 variant stands out as the third major variant of concern. It was identified for the first time in January 2021, when Japan registered four cases of the variant in travelers arriving from Brazil [37]. Recently, the second wave of COVID-19 pandemic which is due to both the old and the new variants of SARS-CoV-2 is hitting the world and we are again under lockdown rules to reduce its spread [38].

The emergence of multiple variants of SARS-CoV-2 has raised concerns in controlling the outbreak of COVID-19 [18, 19]; the recent surge of COVID-19 cases in India, caused by the new SARS-CoV-2 variants B.1.617 and B.1.618, has captured global attention with a record number of new cases reported in a single day $\left(402,110\right.$ cases on April 30 $\left.0^{\text {th }}, 2021\right)$. The hospitals are overcrowded and the health system is unable to cope with the current pandemic situation [40].

\section{COVID-19 control measures}

In the initial phase of the COVID-19 pandemic, while research for discovery of treatment and vaccine was ongoing, public health leaders recommended non-pharmaceutical interventions such as social distancing, lockdown strategies, and proper sanitization as the means to reduce the transmission of the SARS-CoV-2 virus. However, this strategy alone was insufficient to end COVID-19 pandemic [41]. In March 2020, the U.S. Department of Health and Human Services (HSS) started the "Operation Warp Speed" program to expedite the COVID-19 vaccine [42]. On July $14^{\text {th }}$ and August $12^{\text {th }}, 2020$, Moderna and Pfizer companies separately published phase I/II clinical trial data on the COVID-19 vaccine. Currently, three vaccines are authorized and recommended in the United States to prevent COVID-19: BNT162b2vaccine manufactured by Pfizer, Inc., BioNTech; mRNA-1273 vaccine manufactured by Moderna TX, Inc., and JNJ-78436735 vaccine manufactured by Janssen Pharmaceuticals Companies of Johnson \& Johnson (CDC, 2021). For therapy, remdesivir (Veklury), has been approved by the FDA for the treatment of COVID-19 in hospitalized patients aged 12 years and older who weigh at least $40 \mathrm{~kg}$ (CDC, 2020). Additionally, several novel therapeutics, including monoclonal antibodies, are available under the Emergency Use Authorization for early outpatient treatment, and are being tested to evaluate their effectiveness of these therapeutics in people who are at high risk of disease progression (CDC, 2020).

\section{Soap as an effective agent against SARS-CoV-2}

\subsection{Chemistry and cleansing action of soap}

Soaps are the oldest cleansing agents known to humans. Soaps contain a mixture of surfactants, emulsifying agents, copolymers, coloring agents, perfumes, etc. [43]. Chemically, soaps are sodium or potassium salts of saturated or unsaturated long-chain fatty acids that function as surfactant (surface-active) molecules; the long hydrocarbon chain forms a non-polar hydrophobic tail and the ionic carboxylate group forms a polar hydrophilic head [44] (Figure 2 ). Thus, surfactant molecules are water-soluble amphiphiles; in an aqueous environment, the non-polar hydrophobic tail interacts actively with the hydrophobic ends of oil, grease, dirt, and even virus particles. Therefore, the cleansing action of soap is attributed mainly to the 
245 surfactant molecules present in the soap. Surfactants have dynamic surface-active properties 246 that enable them to lower the surface tension of water [45]. The surfactant monomers are 247 adsorbed at the interface, and above a specific threshold, concentration called the critical 248 micelle concentration (CMC), the excess surfactant monomers self-associate to form micellar 249 aggregates [46,47] (Figure 3). The micellar aggregates act as emulsifiers that solubilize 250 molecules such as fat and grease that are otherwise insoluble in aqueous solutions. 251 Micellization is the fundamental characteristic of all surfactants and contributes to their 252 cleansing action against microbial species, including the enveloped viruses. Some important 253 soap ingredients and their useful functions in cleansing and enhancing the antimicrobial 254 property of the soap are reported in table 1. 
255 Table 1: Structure of Soap ingredients and their useful functions

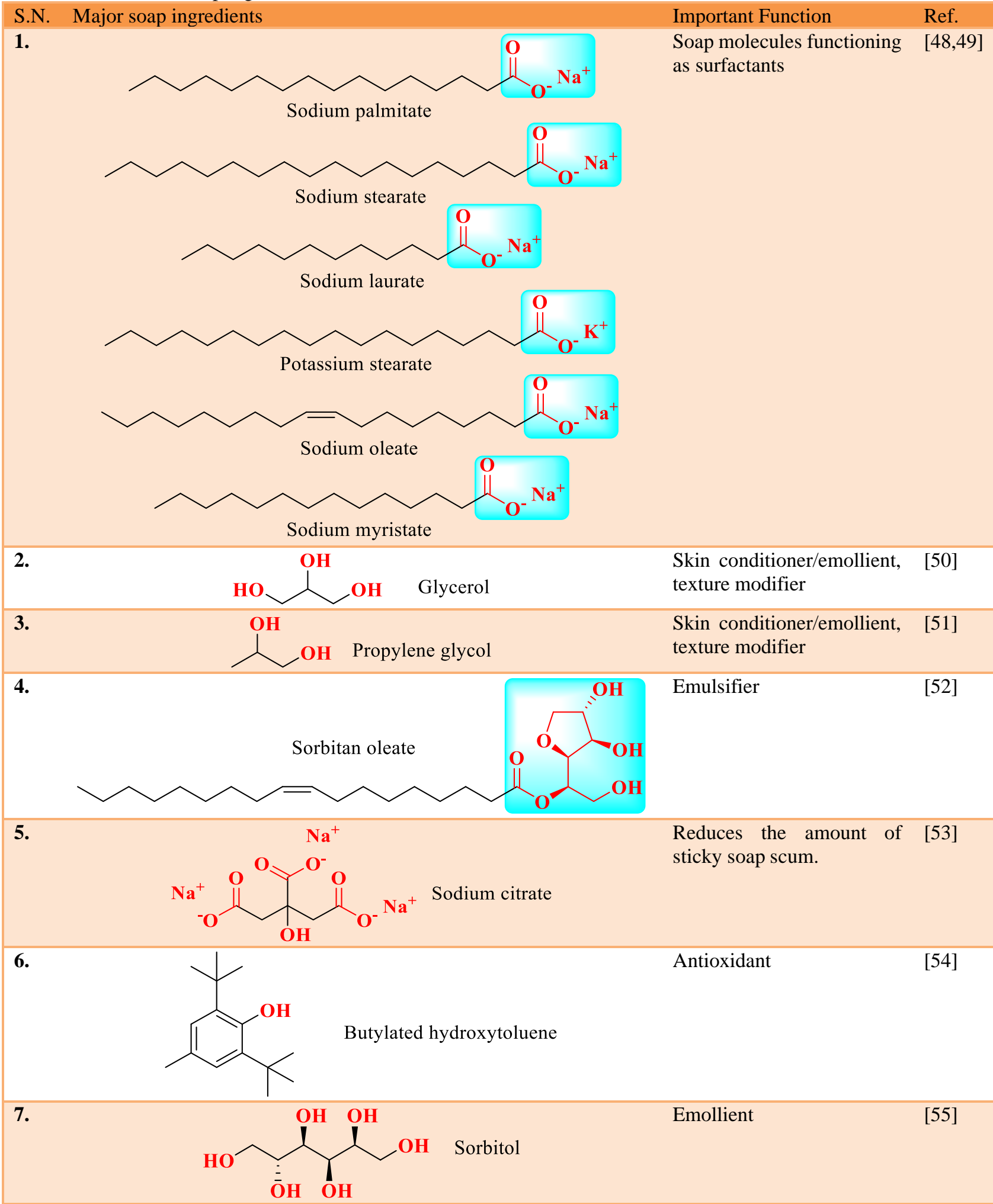




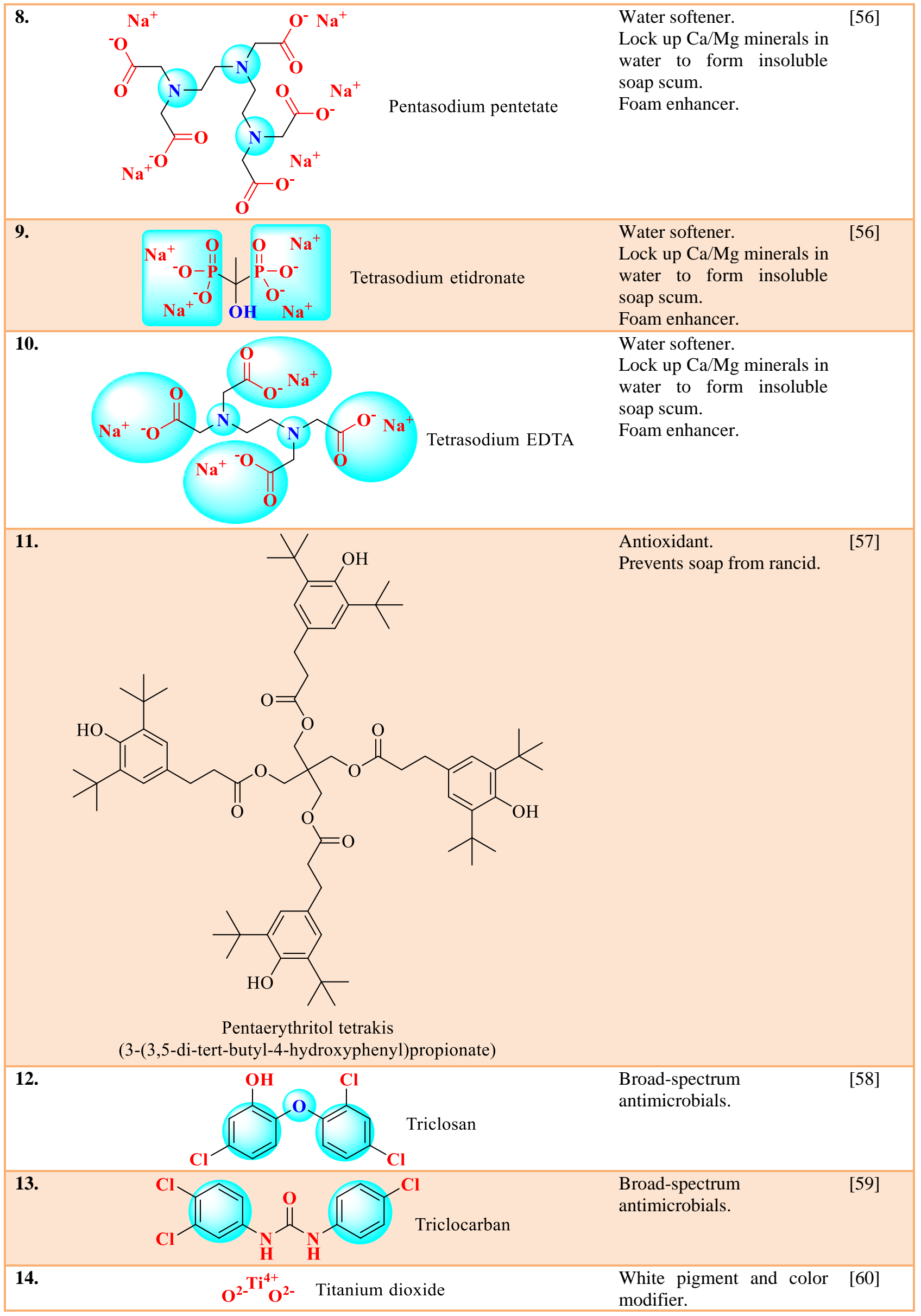


256

257

258

259

260

261

262

263

264

265

266

267

268

269

270

271

272

273

274

275

276

277

278

279

280

281

All commercially available soaps consist of the same basic chemistry described above, and hence have the potential to disrupt the enveloped viruses. The overall cleansing activity of soaps can be attributed to the following properties of soaps [61]:

1) Soaps contain ingredients that can moisten the surface to be cleaned,

2) Soap monomers adsorb on the dirt and virion particles, thereby charging and stabilizing them.

3) Many soaps are alkaline. The basic soap solution (9-10 pH) supports emulsifying and peptizing actions $[62,63]$. Furthermore, the alkalinity of the soaps ( $\mathrm{pH}$ approximately 9-10) promotes the dispersal of microbial flora from the skin [64].

4) Soap solutions have lower surface tension than most of the aqueous solutions; this allows for the thinning of films, thus enabling the emulsifying action.

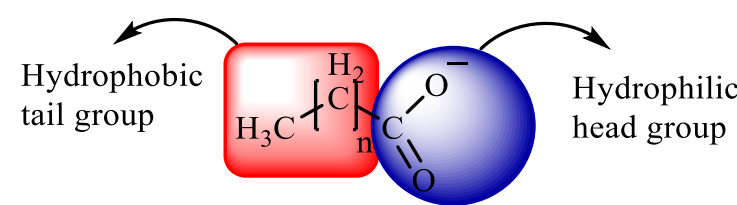

Figure 2. Molecular structure of soap

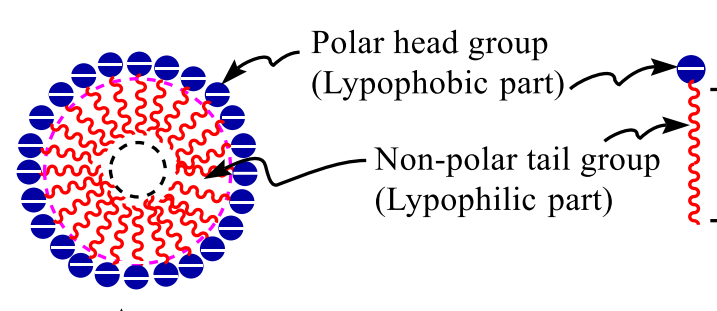

A

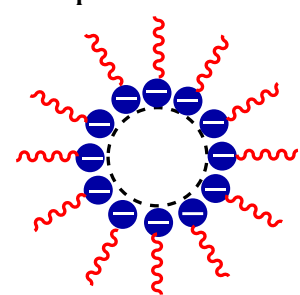

$\mathbf{B}$

Figure 3. Structure of (A) Normal phase micelle (B) Reverse phase micelle

The application of surfactants in the deactivation of viruses is not a new topic. Several targeted studies have reported the deactivation of different viruses by the use of different types of surfactants and products [65-67]. The findings of previous studies on the effectiveness of handwashing using different types of surfactant-based hand hygiene products in reducing different types of viruses are presented in table 2. 
Table 2. Studies on the effectiveness of handwashing using different types of surfactant-based hand hygiene products in reducing different types of viruses

\begin{tabular}{|c|c|c|c|c|c|}
\hline S. N. & Virus & $\begin{array}{l}\text { Cleanser type/ Hand hygiene } \\
\text { product }\end{array}$ & $\begin{array}{l}\text { Inactivation time \& } \\
\text { Effective concentration }\end{array}$ & $\begin{array}{l}\text { Reduction } \\
\text { observed }\end{array}$ & Reference \\
\hline \multirow[t]{2}{*}{1} & \multirow{2}{*}{$\begin{array}{l}\text { HIV-1 } \\
\text { strain: HTLV- } \\
\text { III }_{R F}\end{array}$} & \multirow{2}{*}{$\begin{array}{l}\text { Derma Cidol (containing } 0.5 \% \\
\text { parachlorometaxylenol in a } \\
\text { sodium } \mathrm{C}_{14-16} \text { olefin sulfonate } \\
\text { formula }\end{array}$} & 30 seconds: $1: 5 \& 1: 10$ & \multirow{2}{*}{$\begin{array}{l}\text { More than } \\
99.99 \% \text { of } \\
\text { virus was } \\
\text { inactivated }\end{array}$} & \multirow[t]{2}{*}{ [68] } \\
\hline & & & $\begin{array}{l}60 \text { seconds:1:5, } 1: 10 \\
1: 20 \& 1: 30\end{array}$ & & \\
\hline 2 & Norwalk virus & $\begin{array}{l}\text { Liquid soap (containing } 0.5 \% \\
\text { triclosan) (Fisher Scientific } \\
\text { International) }\end{array}$ & - & $\begin{array}{l}0.67 \pm 0.47 \\
\log _{10}\end{array}$ & [69] \\
\hline 3 & $\begin{array}{l}\text { HIV-1 } \\
\text { Strain: SF33 }\end{array}$ & $\begin{array}{l}\text { Ivory: commercial bar soap } \\
\text { (Johnson \& Johnson) }\end{array}$ & $\begin{array}{l}2 \text { minutes\& } 6 \text { minutes: } \\
1: 1000\end{array}$ & $\begin{array}{l}\text { Infectivity } \\
\text { reduced by } \\
>1000 \text { fold }\end{array}$ & [70] \\
\hline 4 & AIV $\mathrm{H}_{5} \mathrm{~N}_{1}$ & $\begin{array}{l}\text { Lifebuoy (Uniliver Pakistan } \\
\text { Ltd.) }\end{array}$ & $\begin{array}{l}5 \text { minutes: } \\
0.1,0.2 \& 0.3 \%\end{array}$ & $\begin{array}{l}\text { Complete } \\
\text { inactivation }\end{array}$ & [71] \\
\hline 5 & Human rotavirus & $\begin{array}{l}\text { Ivory: Liquid soap } \\
\text { (Procter \& Gamble) }\end{array}$ & $1: 10$ & $86.9 \pm 2.42 \%$ & [72] \\
\hline \multirow[t]{2}{*}{6} & \multirow[t]{2}{*}{$\begin{array}{l}\text { MS2- } \\
\text { Bacteriophage }\end{array}$} & $\begin{array}{l}\text { Foaming hand soap (GOJO } \\
\text { Industries, Akron, } \mathrm{OH})\end{array}$ & - & $\begin{array}{l}2.10 \pm 0.57 \\
\log _{10} \mathrm{PFU}\end{array}$ & \multirow[t]{2}{*}{ [73] } \\
\hline & & $\begin{array}{l}\text { Liquid soap (Epare, Staten } \\
\text { Island, New York) }\end{array}$ & - & $\begin{array}{l}2.23 \pm 0.51 \\
\log _{10} \text { PFU }\end{array}$ & \\
\hline \multirow[t]{6}{*}{7} & \multirow[t]{6}{*}{$\begin{array}{l}\text { Respiratory } \\
\text { syncytial virus }\end{array}$} & $\begin{array}{l}\text { Bac-Down (Decon } \\
\text { Laboratories) }\end{array}$ & 5 minutes: $0.045 \%$ & \multirow[t]{6}{*}{$\begin{array}{l}90 \% \\
\text { Inactivation }\end{array}$} & \multirow[t]{6}{*}{ [74] } \\
\hline & & Soft N Sure & 5 minutes: $0.280 \%$ & & \\
\hline & & $\begin{array}{l}\text { Cida-Stat (Ecolab Professional } \\
\text { Products) }\end{array}$ & 5 minutes: $0.333 \%$ & & \\
\hline & & Alo Guard (Health Link) & 5 minutes: $0.360 \%$ & & \\
\hline & & $\begin{array}{l}\text { Hibiclens (Zeneca } \\
\text { Pharmaceuticals) }\end{array}$ & 5 minutes: $0.390 \%$ & & \\
\hline & & Kindest Care (Steris) & 5 minutes: $0.390 \%$ & & \\
\hline
\end{tabular}

\subsection{Mechanisms of inactivation of SARS-CoV by soap}

The mechanism of cleansing action of soap is based on a general principle of chemistry "like dissolves like". We suggest three possible mechanisms for the deactivation of SARS-CoV by soap.

\section{Membrane rupture mechanism}

As described previously, the lipid membrane in SARS-CoV and most other enveloped viruses

294 is a bilayer composed of water-insoluble amphiphiles, particularly phospholipids and 295 membrane proteins [75]. Upon addition of a surfactant solution, the phospholipid in the bilayer 296 and the surfactant monomers interact via hydrophobic-hydrophobic interactions between the 297 lipid tails and the surfactant tails and vice versa. At low surfactant concentrations (i.e., below 298 CMC), part of the added surfactants is inserted into the bilayer, competing with the 299 phospholipids, thus disturbing the orderly arranged structure of the membrane while the rest of 300 the surfactant remains as monomers in the aqueous solution [76]. When the surfactant 301 concentration reaches the CMC, the lipid-surfactant mixed bilayers become saturated and no 302 longer accommodate additional surfactants. This induces solubilization of the phospholipids 303 via phase transformation of the mixed bilayer into mixed (lipid-surfactant) micelles. At this 304 stage, the surfactant-saturated bilayer remains in thermodynamic equilibrium with the mixed 305 micelles [77,78]. Above CMC, when the surfactant-to-lipid concentration ratio increases, 
306

307

308

309

310

311

312

micellization is completed, i.e., the lipid bilayer is completely solubilized by the surfactants and only the micellar aggregates remain in the solution [79]. Thus, the complete solubilization of the protective lipid bilayer leads to the disintegration of the virus into fragments, making it no longer infective. Further, the fragmented viral components are also completely solubilized by the surfactant molecules in the form of micelles, which can then be easily washed away by water (Figure 4).

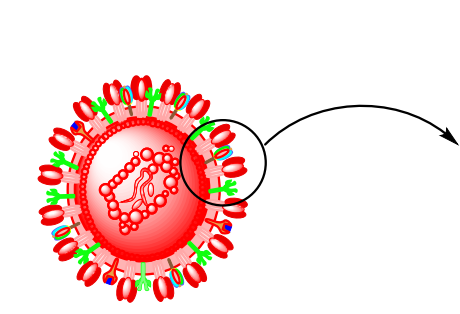

(a) A single SARS-Cov-2 entity

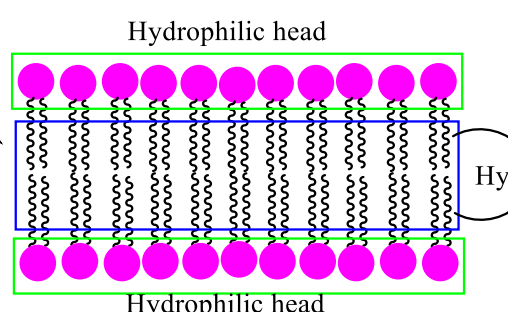

Hydrophilic head

(b) Enlarged view of lipid bilayer<smiles>C=CC(=C)[GeH2][SeH2]</smiles>

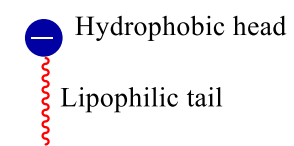

(c) A soap monomer
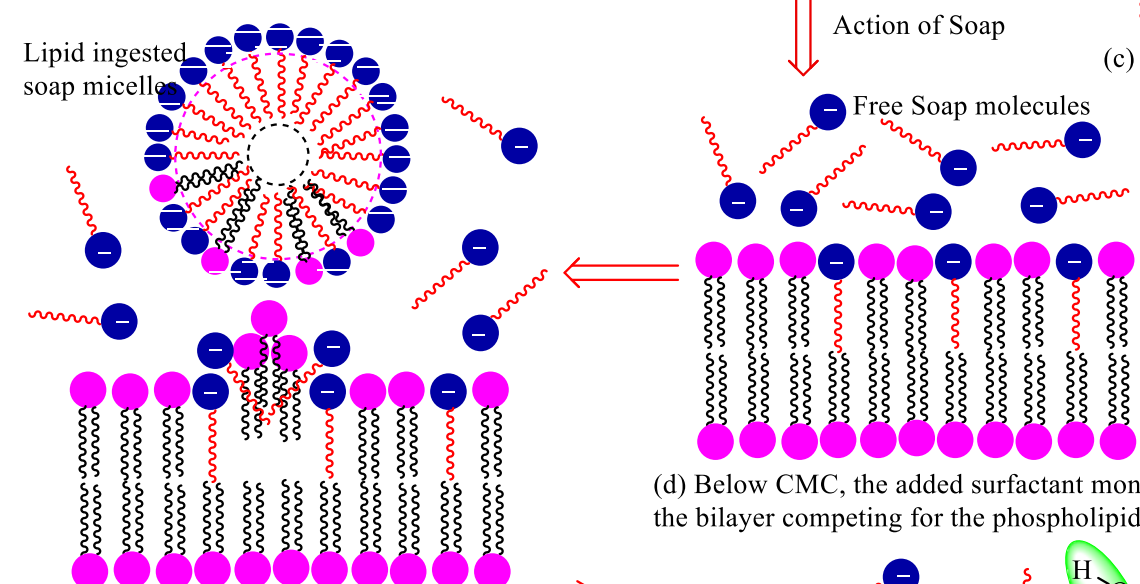

(d) Below CMC, the added surfactant monomers inters into the bilayer competing for the phospholipids in the membrane

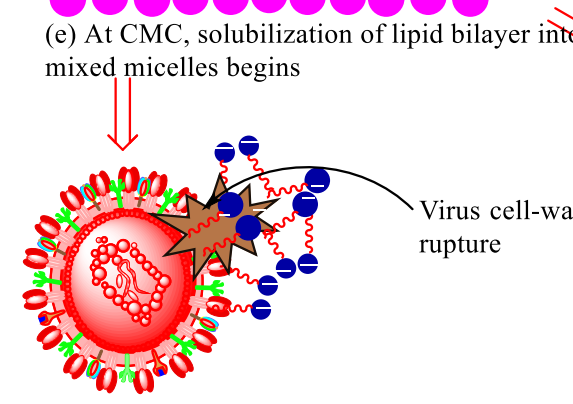

Rupturing of virus cell wall by soap molecules

(f) Above CMC, complete solubilization of the outer lipid bilayer into mixed micelles, followed by the entraping of the viral fragments within the soap micelles occur.

Figure 4. Diagrammatic representation of membrane ruptures mechanism

\section{Simple elution mechanism}

In general, a minimum of 20 seconds of handwashing with soap and water is shown to be effective in the removal of oily particles $[80,81]$. However, the complete inactivation of viruses within such a short time of interaction cannot be asserted by the membrane rupture mechanism. Previous studies have reported the inactivation of viruses by soap solutions [39, 42]. However, the interaction time in those studies $(5 \mathrm{~min})$ does not mimic common day-to-day conditions. 
323

324

325

326

327

328

329

330

331

332

333

334

335

336

337

338

Therefore, there must be a mechanism of virus or dirt removal without necessarily inactivating them. We have proposed a possible mechanism as the 'simple elution' mechanism.

The outer lipid layer of SARS-CoV and other enveloped viruses enables their adsorption on the host cell surface [82]. Soap solutions have a very low surface tension because which they can form very thin films [32]. As a result, they can enter into tiny spaces and spread fluently around the dirt particles, including viruses. Also, soap has the potential to moisten the surface and get adsorbed on any foreign particles present, thereby charging and stabilizing them. The amphiphilic nature of soap, in particular the attractive interaction between the hydrophobic ends of soap with hydrophobic lipid membranes, supports the adsorption of soap monomers. The charged viral particles cannot aggregate. Further, their adsorptive property is lost and they are dragged along with water molecules while washing (Figure 5). Within20 seconds of handwashing recommended by the WHO, the viral component cannot be completely inactivated but can be successfully removed from the hand surface. Therefore, there is a substantial rationale for the existence of a 'simple elution' mechanism, especially attributed to general handwashing.

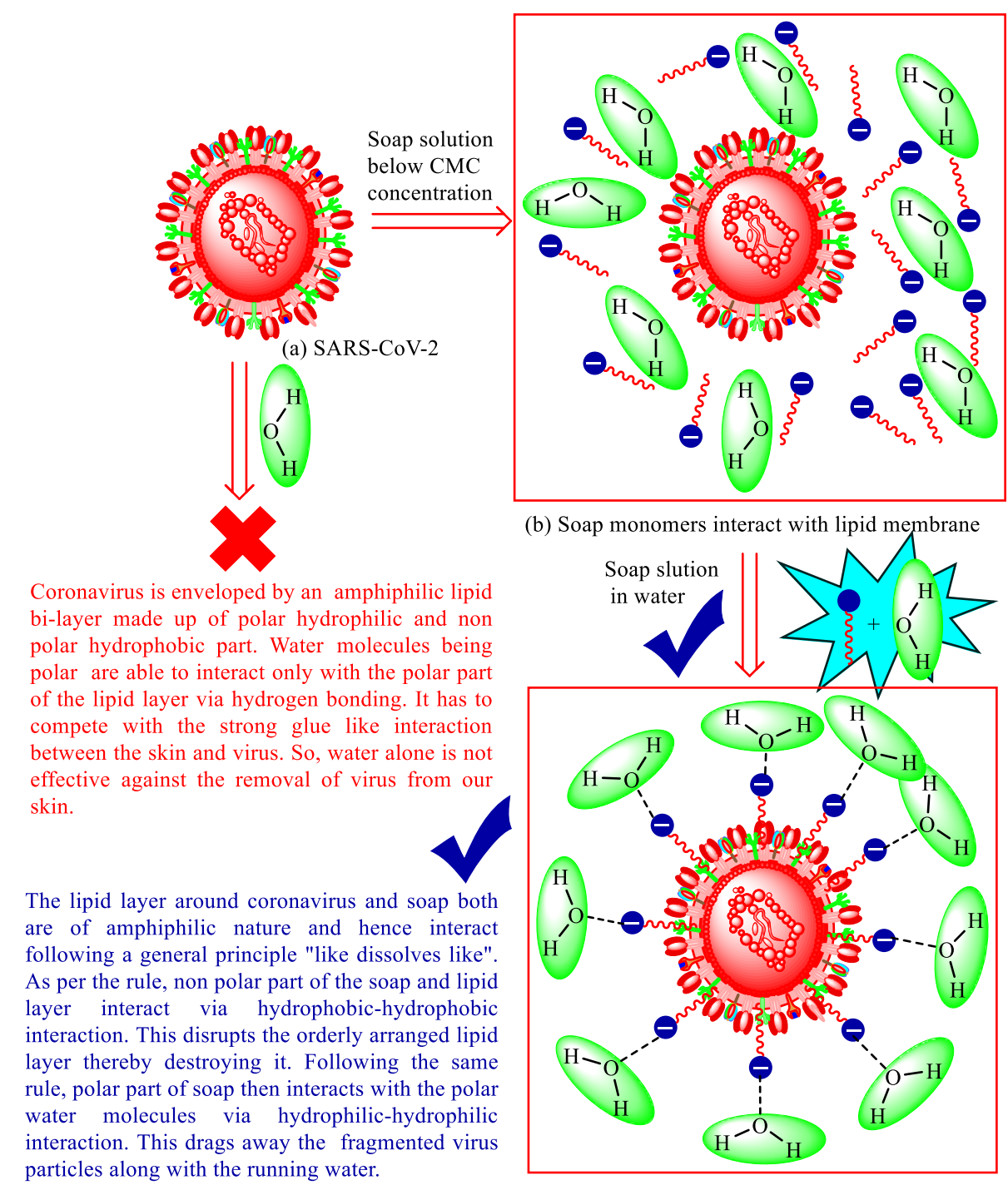

(c) Charged virus suspended in soap solution, which can be easily eluted with water during washing 
343

344

345

346

347

348

349

350

351

352

353

354

355

356

357

358

359

360

361

362

363

In a study examining the elution of bacteriophages Phi X174 and PRD1 bound to nitrocellulose and charged modified polyether sulfonate membranes, excellent elution of both bacteriophages was achieved using 5mM SDS (Sodium Dodecyl Sulfate) from the BioTrace HP membrane. However, minimum inactivation of PDRI was obtained by $10 \mathrm{mM}$ SDS within four min. of exposure, while phiX174 remained unaffected even with 50mM of SDS [83]. These findings support the elution mechanism and that soaps can remove viruses from the adsorbed surfaces even when they are not completely able to inactivate the viruses.

\section{Viral entrapment mechanism:}

As described earlier, SARS-CoV-2 and other enveloped viruses resemble fatty particles of nano-scale diameter. A third probable mechanism involves complete entrapment of the viral particle into the soap micelle. When the surfactant concentration exceeds the CMC value, micellization begins. The soap micelle so formed entraps the viral cell into its nucleus via hydrophobic-hydrophobic interactions. The water molecules then bind with the hydrophilic heads of the micelles, thereby dragging away the entrapped viral cell along with washing (Figure 6). However, since the soap micelles are also of nano-scale diameter, they may not be able to engulf the viral cell as a whole. Further, there is no prior evidence to support this mechanism. Further investigation is required to determine the viability of the proposed mechanism.

364

365

366

367

368

369

370

371

372

373

374

375

376

377

378

379

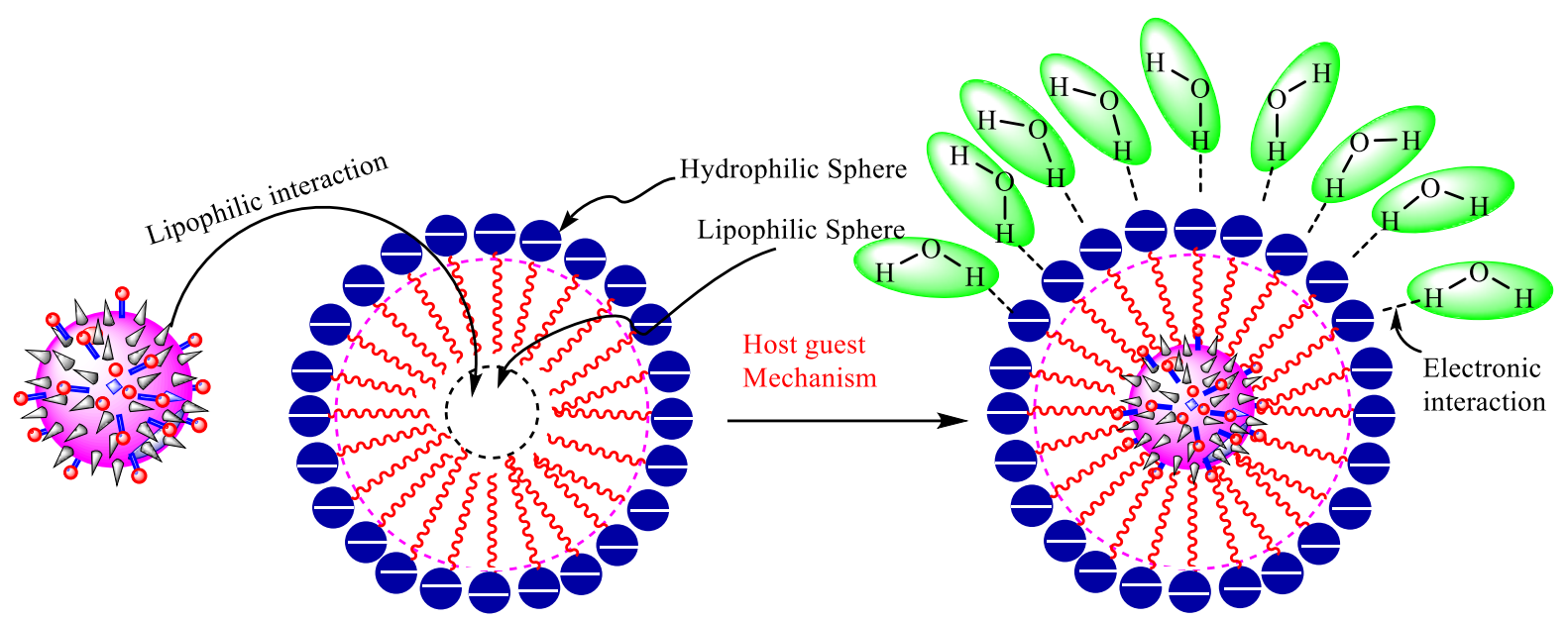

Figure 6. Diagrammatic representation of the viral entrapment mechanism

Regarding the effectiveness of handwashing in the control and prevention of SARS-CoV-2 and other viruses, the duration of washing has been shown to have a significant effect on controlling the disease. However, no distinction between the mechanisms is possible, and often they may operate simultaneously. Together, the surfactant action of soaps combined with the friction caused during handwashing and final rinsing with clean water is a very effective method for the removal of dirt as well as microbes [84]. For the mechanisms to function effectively, proper rubbing between hands for an adequate amount of time is important. Using soap and detergent at $0.1,0.2$, and $0.3 \%$ concentrations completely inactivated the H5N1 virus within 5 min [39]. In a recent study, handwashing was associated with a greater risk of spread of influenza-like illness compared to hand-washings for 15 seconds or longer [85,86]. Because of the effectiveness of the method, handwashing with soap and water has been tagged as the "gold standard" method for removing dirt and transient flora from the hand [84]. Both soap and 
380 alcohol-based sanitizers are effective in controlling COVID-19 when applied to hands

381

382

383

384

385

386

387

388

389

390

391

392

393

394

395

396

397

398

399

400

401

402

403

404

405

406

407

408

409

410

411

412

413

414

415

416

417

418

419

420

421

422

423

424

425

426

427

428

429

thoroughly and with scrubbing for at least $20 \mathrm{~s}[47,48]$.

\subsection{Why Soap is better than an alcohol-based sanitizer}

The very important message throughout such COVID pandemic has been the need for people to wash their hands regularly and thoroughly. While soap and water are best, hand sanitizer is a good substitute in high populations areas or when suitable hand-washing facilities are not available [87]. As we noticed that people are using hand sanitizer daily, sometimes multiple times a day, so the U.S. Food and Drug Administration (FDA) has decided that the companies making hand sanitizers need to provide proof that those chemicals are safe for that level of exposure, especially for pregnant women and children. Three active ingredients (benzalkonium chloride, ethyl alcohol, and isopropyl alcohol) are still under review. According to a new study, quickly smearing an ethanol-based hand sanitizer onto your hands won't kill cold and flu bugs. This is because your fingers are still wet with mucus. It is interesting that FDA has treated sanitizers as 'over-the-counter drugs' and recommended the use of soap and water over sanitizers. The FDA's recommendation on sanitizers is very sensitive to impurities or adulterants [88].

If we don't have access to soap and water, then hand sanitizer containing $60 \%$ alcohol is a good temporary substitute for neutralizing the coronavirus. Soap provides dual advantage; it neutralizes the coronavirus and also physically knocks it off our hands; soap disrupts the sticky bond between pathogens and our skin, allowing the pathogens to slide right off. Hand sanitizer doesn't do all of that. Besides, hand sanitizers may penetrate deeper into the skin layers and affect the skin cells [89].The use of methanol as an adulterant in hand sanitizers and hand rubs is another concern [90]. Methanol must never be used in hand sanitizers because oral, pulmonary, and/or skin exposures can result in allergic reactions, severe systemic toxicity and even death [91]. Using soap and water is safer and hence recommended.

\subsection{Role of polyelectrolytes in soaps}

Many soaps, shampoos, and cosmetics incorporate polyelectrolytes [92,93] and polyelectrolyte builder materials that serve to enhance the cleaning capacity of soaps [94]. The polyelectrolytes have several applications, mostly related to modifying the flow and stability properties of aqueous solutions and gels. For instance, they can be used to destabilize a colloidal suspension and to initiate flocculation (precipitation). When mixed with surfactants, they form polyelectrolyte-surfactant complexes (PESC) spontaneously by self-assembly driven by electrostatic and hydrophobic interactions. PESC containing sodium lauryl ether sulfates (SLES) have found wide application in hair care products such as shampoos and soaps [95]. Sodium polyacrylate, an anionic polyelectrolyte retains water molecules and increases the viscosity, hence it is often used in soaps as a thickening agent [96].

Generally, soap compositions include, by weight, $30 \%$ to $60 \%$ surfactant, $1 \%$ to $35 \%$ polysaccharide (strong polyelectrolyte), $1 \%$ to $10 \%$ fatty acid, and $25 \%$ to $50 \%$ polymer matrix, of the total weight of the soap composition. The soap compositions may further include a fragrance-generating chemical in an amount of $0.1 \%$ to $2 \%$ by weight of the soap composition. 
430

431

432

433

434

435

436

437

438

439

440

441

442

443

444

445

446

447

448

449

450

451

452

453

454

455

456

457

458

459

460

461

462

463

464

465

466

467

468

469

470

471

472

473

474

475

476

477

478

479

\subsection{Effect of temperature on inactivation of SARS-CoV-2 by soap}

Besides using soaps and hand sanitizers, another measure that is being explored as a control measure is the inactivation of coronavirus at high temperatures. Using hot water with soap or detergent has been believed to be more effective for cleaning, mainly because high temperatures increase the thermodynamic activity as well as the penetrating ability of the surfactant molecules [97]. However, an increase in the temperature of detergents such as Sodium-lauryl-sulphate (SLS) increases transcutaneous penetration, which can damage the rough outer layer of the skin $[98,99]$. Further, an increase in temperature also discourages micellization. Therefore, while the use of hot water is believed to have a greater cleansing action, its disruptive effects on our skin should be carefully considered, especially for applications such as frequent handwashing. The particular effects that should be considered are:

1) The activity of the virus decreases at higher temperatures,

2) The activity and penetration of surfactants increased with an increase in temperature,

3) At higher temperatures, the activation energy increases, as a result, the cleansing activity of the surfactants (soaps and detergents) also increases,

4) The absorption of surfactants through the skin depends on the activation energy $[98,100]$.

At higher temperatures, the activation energy increases. This causes increased dermal penetration of surfactants and chemicals. As a result, high amounts of surfactants will be absorbed by the skin, which will negatively affect the health of the user. For these reasons, utilization of high temperature to control the virus are more suitable for disinfecting clothing and other fomites, than for frequent handwashing.

\section{Conclusion:}

The SARS-CoV-2 (COVID-19) pandemic necessitated the quick implementation of effective control strategies to stop the spread of the disease. While efforts to discover therapeutics and vaccines were ongoing, countries across the globe adopted measures to reduce transmission of the SARS-CoV-2 virus mainly by social distancing and maintaining hand hygiene via frequent handwashing with soap and water and using alcohol-based hand sanitizers. We discussed the cleansing action of soap on SARS-CoV-2 and the mechanisms by which soap potentially eliminates the virus. Soaps are amphiphilic substances capable of interacting with hydrophilic as well as hydrophobic substances. In summary, their effectiveness is attributed to: a) low surface tension in solution, b) basic nature, c) amphiphilic orientation, and d) capacity to form a micelle. The lipid envelope of SARS-CoV-2 is vulnerable to amphiphilic chemicals like soap. The cleansing mechanisms of surfactants can follow either by i) destroying the lipid membrane of the virus, ii) entrapment of the viral particle within, the soap micelle, or by iii) elution or the viral particles by adsorption of soap monomers on the viral surface, charging and stabilizing them, all of which are then removed by water. Additionally, elimination of the virus using high temperature could also be considered for disinfection of contaminated fomites. Hand-washing with soap and water is extensively practiced. Based on the evidence provided by our analysis, we conclude that handwashing with soap and water effectively reduces the risk of viral infections. When practiced following the recommended protocol, it may potentially reduce the spread of SARS-CoV-2 (COVID-19).

\section{Funding}

This research didn't receive grants from any funding agency in the public, commercial or notfor-profit sectors. 
480

481

482

483

484

485

486

487

488

489

490

491

492

493

494

495

496

497

498

499

500

501

502

503

504

505

506

507

508

509

510

511

512

513

514

515

516

517

518

519

520

521

522

523

524

525

526

527

528

529

\section{Authors' contributions}

N.K.C. and A.B. conceptualized the purpose of the study. N.K.C., B.G., and S.R. prepared the first draft of the manuscript. K.M.S., N.C., and R.C. designed the manuscript. M.D. reviewed the microbiology, N.K.C., R.L.K., and A.B. critically revised and reviewed the manuscript. All authors have read and agreed to publish this version of the manuscript.

\section{Conflicts of interest:}

Authors declare no competing interests.

\section{References}

[1] Li G, Fan Y, Lai Y, Han T, Li Z, Zhou P, et al. Coronavirus infections and immune responses. J Med Virol 2020;92(4):424-432. https://doi.org/10.1002/jmv.25685.

[2] Sherin A. Coronavirus disease 2019 (COVID-19): A challenge of protecting the general population and health-care workers. Khyber Med Univ J 2020;12:4-5. https://doi.org/10.35845/kmuj.2020.20224.

[3] Udwadia ZF, Raju RS. How to protect the protectors: 10 lessons to learn for doctors fighting the COVID-19 Coronavirus. Med J Armed Forces India 2020:1-5. https://doi.org/10.1016/j.mjafi.2020.03.009.

[4] Morens DM, Breman JG, Calisher CH, Doherty PC, Hahn BH, Keusch GT, et al. The Origin of COVID-19 and Why It Matters. Am J Trop Med Hyg 2020;103(3):955-959. https://doi.org/10.4269/ajtmh.20-0849.

[5] Shereen MA, Khan S, Kazmi A, Bashir N, Siddique R. COVID-19 infection: Origin, transmission, and characteristics of human coronaviruses. J Adv Res 2020;24:91-98. https://doi.org/10.1016/j.jare.2020.03.005.

[6] Kar SK, Yasir Arafat SM, Kabir R, Sharma P, Saxena SK. Coping with mental health challenges during COVID-19. Coronavirus Dis. 2019 (COVID-19), Med. Virol. From Pathog. to Dis. Control, vol. 2019. S. K. Saxe, Springer Nature Singapore Pte Ltd.; 2020; 199-213. https://doi.org/10.1007/978-981-15-4814-7_16.

[7] Beiu C, Mihai M, Popa L, Cima L, Popescu MN. Frequent hand washing for COVID19 prevention can cause hand dermatitis: management tips. Cureus 2020;12. https://doi.org/10.7759/cureus.7506.

[8] World Health Organization. Recommendations to Member States to improve hand hygiene practices to help prevent the transmission of the COVID-19 virus. 2020. Available online: https://www.who.int/publications/i/item/recommendations-tomember-states-to-improve-hand-hygiene-practices-to-help-prevent-the-transmissionof-the-covid-19-virus (accessed on 1 April 2020)

[9] Food and Agriculture Organization of the United Nations, World Health Organization. COVID-19 and food safety: guidance for food businesses. 2020. Available online: https://www.who.int/publications/i/item/covid-19-and-food-safety-guidance-for-foodbusinesses (accessed on 7 April 2020)

[10] Hassan SA, Sheikh FN, Jamal S, Ezeh JK, Akhtar A. Coronavirus (COVID-19): a review of clinical features, diagnosis, and treatment. Cureus 2020;12. https://doi.org/10.7759/cureus.7355.

[11] CEBM. Coronaviruses- a general introduction. 2020. Available online: https://www.cebm.net/covid-19/coronaviruses-a-general-introduction/ (Accessed on 25 March 2020) 
530 [12] Wege H, Siddell S, ter Meulen V. The biology and pathogenesis of coronaviruses. Curr.

531

532

533

534

535

536

537

538

539

540

541

542

543

544

545

546

547

548

549

550

551

552

553

554

555

556

557

558

559

560

561

562

563

564

565

566

567

568

569

570

571

572

573

574

575

576

577

578

579
Top. Microbiol. Immunol., Springer Berlin Heidelberg; 1982, p. 165-200. https://doi.org/10.1007/978-3-642-68528-6_5.

[13] WHO. Coronavirus disease (COVID-19) outbreak. 2020. Available online: https://www.euro.who.int/en/health-topics/health-emergencies/coronavirus-covid19/novel-coronavirus-2019-ncov

[14] Wilder-smith A, Chiew CJ, Lee VJ. Can we contain the COVID-19 outbreak with the same measures as for SARS ? Lancet Infect Dis 2020, 20(5), p. e102-e107. https://doi.org/10.1016/S1473-3099(20)30129-8.

[15] Weiss SR, Navas-martin S. Coronavirus pathogenesis and the emerging pathogen severe acute respiratory syndrome coronavirus. Microbiol Mol Biol Rev 2005;69:635-64. https://doi.org/10.1128/MMBR.69.4.635.

[16] Hogue BG, Machamer CE. Coronavirus structural proteins and virus assembly. In: Perlman S, Gallagher T, Snijder EJ, editors. Nidoviruses, ASM Press, Washington, DC; 2008, p. 179-200.

[17] Schoeman D, Fielding BC. Coronavirus envelope protein : current knowledge. Virol J 2019;16. https://doi.org/10.1186/s12985-019-1182-0.

[18] Tripet B, Howard MW, Jobling M, Holmes RK, Holmes K V, Hodges RS. Structural characterization of the SARS-Coronavirus spike S fusion protein core. J Biol Chem 2004;279(20):20836-20849. https://doi.org/10.1074/jbc.M400759200.

[19] Rosa G La, Fratini M, Libera S Della, Iaconelli M, Muscillo M. Viral infections acquired indoors through airborne, droplet or contact transmission. Ann Ist Super Sanità 2013;49(02):124-32. https://doi.org/10.4415/ANN_13_02_03.

[20] Geller C, Varbanov M, Duval RE. Human coronaviruses: insights into environmental resistance and its influence on the development of new antiseptic strategies. Viruses 2012;4(11):3044-3068. https://doi.org/10.3390/v4113044.

[21] Sola I, Mateos-Gomez PA, Almazan F, Zuñiga S, Enjuanes L. RNA-RNA and RNAprotein interactions in coronavirus replication and transcription. RNA Biol 2011;8(2):237-48. https://doi.org/10.4161/rna.8.2.14991.

[22] Daga MK, Kumar N, Aarthi J, Mawari G, Garg S, Rohatgi I. From SARS-CoV to coronavirus disease 2019 (COVID-19) - a brief review. J Adv Res Med 2019;6:1-9. https://doi.org/10.24321/2349.7181.201917.

[23] Centers for Disease Control and Prevention. Symptoms of COVID-19. 2021. Available online: https://www.cdc.gov/coronavirus/2019-ncov/symptoms-testing/symptoms.html (Accessed on 22 February 2021)

[24] Pyrc K, Berkhout B, van der Hoek L. Identification of new human coronaviruses. Expert Rev Anti Infect Ther 2007;5:245-53. https://doi.org/10.1586/14787210.5.2.245.

[25] Wevers BA, van der Hoek L. Recently discovered human coronaviruses. Clin Lab Med 2009;29:715-24. https://doi.org/10.1016/j.cll.2009.07.007.

[26] Alsaadi EAJ, Jones IM. Membrane binding proteins of coronaviruses. Future Virol 2019;14:275-86.

[27] Hiscott J, Alexandridi M, Muscolini M, Tassone E, Palermo E, Soultsioti M, et al. The global impact of the coronavirus pandemic. Cytokine Growth Factor Rev 2020. https://doi.org/10.1016/j.cytogfr.2020.05.010.

[28] Bontempi E. The europe second wave of COVID-19 infection and the Italy "strange" situation. Environ Res 2020:110476. https://doi.org/10.1016/j.envres.2020.110476.

[29] González-Bustamante B. Evolution and early government responses to COVID-19 in South America. World Dev 2021;137:105180. https://doi.org/10.1016/j.worlddev.2020.105180.

[30] Worldometer. COVID live update: 160,416,106 cases and 3,333,785 deaths from the 
580

581

582

583

584

585

586

587

588

589

590

591

592

593

594

595

596

597

598

599

600

601

602

603

604

605

606

607

608

609

610

611

612

613

614

615

616

617

618

619

620

621

622

623

624

625

626

627

628

629
Coronavirus. 2021. Available online: https://www.worldometers.info/coronavirus/ (Accessed on 16 May 2021)

[31] Wu A, Wang L, Zhou H, Ji C, Xia SZ, Cao Y, et al. One year of SARS-CoV-2 evolution. Cell Host Microbe 2021;29:503-7. https://doi.org/10.1016/j.chom.2021.02.017.

[32] Guruprasad L. Human SARS CoV-2 spike protein mutations. Proteins 2021;89:569-76. https://doi.org/10.1002/prot.26042.

[33] Zhang L, Jackson CB, Mou H, Ojha A, Rangarajan ES, Izard T, et al. The D614G mutation in the SARS-CoV-2 spike protein reduces S1 shedding and increases infectivity. BioRxiv Prepr 2020. https://doi.org/10.1101/2020.06.12.148726.

[34] Hodcroft EB, Zuber, Moira1. Hodcroft EB et al. E and spread of a S-C-2 variant through $E$ in the summer of 2020. medRxiv 2020. 10. 25. 2021906. (2020)., Nadeau S, Comas I, González Candelas F, Consortium S-S, et al. Emergence and spread of a SARS-CoV-2 variant through Europe in the summer of 2020. MedRxiv 2020:2020.10.25.20219063.

[35] Centers for Disease Control and Prevention (CDC). About variants of the Virus that causes COVID-19. 2021. Available online: https://www.cdc.gov/coronavirus/2019ncov/transmission/variant.html (Accessed on 2 April 2021).

[36] Kirby T. New variant of SARS-CoV-2 in UK causes surge of COVID-19. Lancet Respir Med 2021;9:e20-1. https://doi.org/10.1016/S2213-2600(21)00005-9.

[37] The Guardian. Brazilian Covid variant: what do we know about P1? 2021. Available online: https://www.theguardian.com/world/2021/mar/01/brazil-covid-variant-p1britain (Accessed on 8 April 2021)

[38] Korber B, Fischer WM, Gnanakaran S, Yoon H, Theiler J, Abfalterer W, et al. Tracking changes in SARS-CoV-2 spike: evidence that D614G increases infectivity of the COVID-19 $\quad$ virus. Cell 2020;182:812-827.e19. https://doi.org/10.1016/j.cell.2020.06.043.

[39] Edara VV, Norwood C, Floyd K, Ahmed R, Wrammert J, Suthar MS, et al. Infectionand vaccine-induced antibody binding and neutralization of the B . 1 . 351 SARS-CoV2 variant. Cell Host Microbe 2021;29:516-521.e3. https://doi.org/10.1016/j.chom.2021.03.009.

[40] Rozanova L, Temerev A, Flahault A. Comparing the scope and efficacy of COVID-19 response strategies in 16 countries: An overview. Int J Environ Res Public Health 2020;17:1-17. https://doi.org/10.3390/ijerph17249421.

[41] Weintraub RL, Subramanian L, Karlage A, Ahmad I, Rosenberg J. COVID-19 Vaccine To Vaccination: Why Leaders Must Invest In Delivery Strategies Now. Health Aff 2021;40:33-41. https://doi.org/10.1377/hlthaff.2020.01523.

[42] Van Norman GA. "Warp Speed" Operations in the COVID-19 Pandemic: Moving Too Quickly? JACC Basic to Transl Sci 2020;5:730-4. https://doi.org/10.1016/j.jacbts.2020.06.001.

[43] Chaudhary NK, Bhattarai A, Guragain B, Bhattarai A. Conductivity, surface tension, and comparative antibacterial efficacy study of different brands of soaps of Nepal. J Chem 2020;2020. https://doi.org/10.1155/2020/6989312.

[44] Hill M, Moaddel T. Soap structure and phase behavior. 2nd ed. Elsevier Ltd.; 2016. https://doi.org/10.1016/B978-1-63067-065-8.50002-5.

[45] Wolfrum S, Marcus J, Touraud D, Kunz W. Historical perspective A renaissance of soaps ? - How to make clear and stable solutions at neutral $\mathrm{pH}$ and room temperature. Adv Colloid Interface Sci 2016:1-15. https://doi.org/10.1016/j.cis.2016.07.002.

[46] Llchtenberg D. Characterization of the solubilization of lipid bilayers by surfactants. Biochim Biophys Acta 1985;821:470-8. https://doi.org/10.1016/0005-2736(85)900525.

[47] Sehgal P, Doe H, Bakshi MS. Solubilization of phospholipid vesicular structures into 
634

635

636

637

638

639

640

641

642

643

644

645

646

647

648

649

650

651

652

653

654

655

656

657

658

659

660

661

662

663

664

665

666

667

668

669

670

671

672

673

674

675

676

677

678

679

mixed micelles of zwitterionic surfactants. J Surfactants Deterg 2003;6:31-7. https://doi.org/10.1007/s11743-003-0245-6.

[48] Moldovan M, Nanu A. Influence of cleansing product type on several skin parameters after single use. Farmacia 2010;58:29-37.

[49] Willcox M. Soap. Poucher's Perfum. Cosmet. Soaps. 10th ed., Kluwer Academic Publishers; 2000, p. 453-65.

[50] Becker LC, Bergfeld WF, Belsito D V., Hill RA, Klaassen CD, Liebler DC, et al. Safety assessment of glycerin as used in cosmetics. Int J Toxicol 2019;38:6S-22S. https://doi.org/10.1177/1091581819883820.

[51] Perencevich EN, Wong MT, Harris AD. National and regional assessment of the antibacterial soap market: A step toward determining the impact of prevalent antibacterial soaps. Am J Infect Control 2001;29:281-3. https://doi.org/10.1067/mic.2001.115469.

[52] Brandner JD. The composition of NF-defined emulsifiers: Sorbitan monolaurate, monopalmitate, monostearate, monooleate, polysorbate 20 , polysorbate 40 , polysorbate 60, and polysorbate 80. Drug Dev Ind Pharm 1998;24:1049-54. https://doi.org/10.3109/03639049809089948.

[53] Mabrouk ST. Making usable, quality opaque or transparent soap. J Chem Educ 2005;82:1534-7. https://doi.org/10.1021/ed082p1534.

[54] Yehye WA, Rahman NA, Ariffin A, Abd Hamid SB, Alhadi AA, Kadir FA, et al. Understanding the chemistry behind the antioxidant activities of butylated hydroxytoluene (BHT): A review. Eur J Med Chem 2015;101:295-312. https://doi.org/10.1016/j.ejmech.2015.06.026.

[55] Hon KL, Kung JSC, Ng WGG, Leung TF. Emollient treatment of atopic dermatitis: latest evidence and clinical considerations. Drugs Context 2018;7:1-14. https://doi.org/10.7573/dic.212530.

[56] George ED, Raymond DJ. Formulation of traditional soap cleansing systems. 2nd ed. Elsevier Ltd.; 2016. https://doi.org/10.1016/B978-1-63067-065-8.50003-7.

[57] Suzuki A, Ulfiati R, Masuko M. Evaluation of antioxidants in rapeseed oils for railway application. Tribol Int 2009;42:987-94. https://doi.org/10.1016/j.triboint.2009.02.001.

[58] Yazdankhah SP, Scheie AA, Høiby EA, Lunestad BT, Heir E, Fotland TØ, et al. Triclosan and antimicrobial resistance in bacteria: An overview. Microb Drug Resist 2006;12:83-90. https://doi.org/10.1089/mdr.2006.12.83.

[59] Breneman DL, Hanifin JM, Berge CA, Keswick BH, Neumann PB. The effect of antibacterial soap with $1.5 \%$ triclocarban on Staphylococcus aureus in patients with atopic dermatitis. Cutis 2000;66:296-300.

[60] Baan R, Straif K, Grosse Y, Secretan B, El Ghissassi F, Cogliano V. Carcinogenicity of carbon black, titanium dioxide, and talc. Lancet Oncol 2006;7:295-6. https://doi.org/10.1016/S1470-2045(06)70651-9.

[61] Hillyer HW. On the cleansing power of soap. J Am Chem Soc 1903;25:511-24. https://doi.org/10.1021/ja02007a010.

[62] Dlova NC, Naicker T, Naidoo P. Soaps and cleansers for atopic eczema, friends or foes? What every South African paediatrician should know about their $\mathrm{pH}$. South African J Child Heal 2017;11:146-8. https://doi.org/10.7196/sajch.2017.v11i3.1325.

[63] Boonchai W, Iamtharachai P. The $\mathrm{pH}$ of commonly available soaps, liquid cleansers, detergents and alcohol gels. Dermatitis 2010;21:154-6. https://doi.org/10.2310/6620.2010.10003.

[64] Lambers H, Piessens S, Bloem A, Pronk H, Finkel P. Natural skin surface $\mathrm{pH}$ is on average below 5, which is beneficial for its resident flora. Int J Cosmet Sci 2006;28:35970. https://doi.org/10.1111/j.1467-2494.2006.00344.x. 
680

681

682

683

684

685

686

687

688

689

690

691

692

693

694

695

696

697

698

699

700

701

702

703

704

705

706

707

708

709

710

711

712

713

714

715

716

717

718

719

720

721

722

723

724

725

726

727

728

729

[65] Lin Q, Lim JYC, Xue K, Yew PYM, Owh C, Chee PL, et al. Sanitizing agents for virus inactivation and disinfection. View 2020;1. https://doi.org/10.1002/viw2.16.

[66] Falk NA. Surfactants as antimicrobials: A brief overview of microbial interfacial chemistry and surfactant antimicrobial activity. J Surfactants Deterg 2019;22:1119-27. https://doi.org/10.1002/jsde.12293.

[67] Piret J, Roy S, Gagnon M, Landry S, Désormeaux A, Omar RF, et al. Comparative study of mechanisms of herpes simplex virus inactivation by sodium lauryl sulfate and nlauroylsarcosine. Antimicrob Agents Chemother 2002;46:2933-42. https://doi.org/10.1128/AAC.46.9.2933-2942.2002.

[68] Lavelle GC, Gubbe SL, Neveaux JL, Bowden BJ. Evaluation of an antimicrobial soap formula for virucidal efficacy in vitro against human immunodeficiency virus in a bloodvirus mixture. Antimicrob Agents Chemother 1989;33:2034-6. https://doi.org/10.1128/AAC.33.12.2034.

[69] Liu P, Yuen Y, Hsiao HM, Jaykus LA, Moe C. Effectiveness of liquid soap and hand sanitizer against Norwalk virus on contaminated hands. Appl Environ Microbiol 2010;76:394-9. https://doi.org/10.1128/AEM.01729-09.

[70] Li JZ, Mack EC, Levy JA. Virucidal efficacy of soap and water against human immunodeficiency virus in genital secretions. Antimicrob Agents Chemother 2003;47:3321-2. https://doi.org/10.1128/AAC.47.10.3321-3322.2003.

[71] Shahid MA, Abubakar M, Hameed S, Hassan S. Avian influenza virus (H5N1); effects of physico-chemical factors on its survival. Virol J 2009;6. https://doi.org/10.1186/1743-422X-6-38.

[72] Ansari SA, Sattar SA, Springthorpe VS, Wells GA, Tostowaryk W. In vivo protocol for testing efficacy of hand-washing agents against viruses and bacteria: Experiments with rotavirus and Escherichia coli. Appl Environ Microbiol 1989;55:3113-8. https://doi.org/10.1128/aem.55.12.3113-3118.1989.

[73] Conover DM, Gibson KE. Comparison of two plain soap types for removal of bacteria and viruses from hands with specific focus on food service environments. Food Control 2016;69:141-6. https://doi.org/10.1016/j.foodcont.2016.04.047.

[74] Contreras PA, Sami IR, Darnell MER, Ottolini MG, Prince GA. Inactivation of respiratory syncytial virus by generic hand dishwashing detergents and antibacterial hand soaps. Infect Control Hosp Epidemiol 1999;20:57-8. https://doi.org/10.1086/501550.

[75] Lichtenberg D, Ahyayauch H, Alonso A, Gon FM. Detergent solubilization of lipid bilayers: a balance of driving forces. Trends Biochem Sci 2013;38:85-93. https://doi.org/10.1016/j.tibs.2012.11.005.

[76] Roth Y, Opatowski E, Lichtenberg D, Kozlov MM. Phase behavior of dilute aqueous solutions of lipid-surfactant mixtures: effects of finite size of micelles. Langmuir 2000;16:2052-61.

[77] Almgren M. Mixed micelles and other structures in the solubilization of bilayer lipid membranes by surfactants. Biochim Biophys Acta - 2000;1508:146-63. https://doi.org/10.1016/S0005-2736(00)00309-6.

[78] Kragh-hansen U, Maire M, Møller J V. The mechanism of detergent solubilization of liposomes and protein-containing membranes. Biophys J 1998;75:2932-46. https://doi.org/10.1016/S0006-3495(98)77735-5.

[79] Koynova R, Tenchov B. Interactions of surfactants and fatty acids with lipids. Curr Opin Colloid Interface Sci 2001;6:277-86.

[80] Tan C. Why washing hands with soap is critical in battling Covid-19. The Straits Times 2020:1-2. Available online: https://www.straitstimes.com/singapore/why-washinghands-with-soap-is-critical-in-battling-covid-19 (Accessed on 15 April 2020) 
730

731

732

733

734

735

736

737

738

739

740

741

742

743

744

745

746

747

748

749

750

751

752

753

754

755

756

757

758

759

760

761

762

763

764

765

766

767

768

769

770

771

772

773

774

775

776

777

778

779

[81] Unicef. Everything you need to know about washing your hands to protect against coronavirus (COVID-19). 2020. Available online: https://www.unicef.org/coronavirus/everything-you-need-know-about-washing-yourhands-protect-against-coronavirus-covid-

19\#: :text=In\%20general\%2C\%20both\%20handwashing\%20with,them\%20with\%20s oap\%20and\%20water. (Accessed on 17 September 2020)

[82] Cosset FL, Lavillette D. Cell entry of enveloped viruses. vol. 73. 2011. https://doi.org/10.1016/B978-0-12-380860-8.00004-5.

[83] Fujito BT, Lytle CD. Elution of viruses by ionic and nonionic surfactants. Appl Environ Microbiol 1996;62:3470-3. https://doi.org/10.1128/aem.62.9.3470-3473.1996.

[84] Foddai ACG, Grant IR, Dean M. Efficacy of instant hand sanitizers against foodborne pathogens compared with hand washing with soap and water in food preparation settings : a systematic review. J Food Prot 2016;79:1040-54. https://doi.org/10.4315/0362-028X.JFP-15-492.

[85] Abdulrahman AK Bin, Abdulrahman KA Bin, Almadi MK, Alharbi AM, Mahmoud MA, Almasri MS, et al. Do various personal hygiene habits protect us against influenzalike illness? BMC Public Health 2019;19:1-8. https://doi.org/10.1186/s12889-0197726-9.

[86] Wesley NO, Talakoub L. Handwashing and hand sanitizer on the skin and COVID-19 infection $\quad$ risk. 2020. Available online: https://www.mdedge.com/dermatology/article/219484/aesthetic-dermatology/handwashing-and-hand-sanitizer-skin-and-covid-19 (Accessed on 23 March 2020)

[87] Dicken RD, Gallagher T, Perks S. Overcoming the regulatory hurdles for the production of hand sanitizer for public health protection: The UK and US academic perspective. ACS Chem Heal Saf 2020;27:209-13. https://doi.org/10.1021/acs.chas.0c00065.

[88] Center for Drug Evaluation and Research. Temporary policy for preparation of certain alcohol-based hand sanitizer products during the public health emergency (COVID-19) guidance for Industry. Pharm. Qual. Stand. (CGMP)/Over-the-Counter, U.S. Department of Health and Human Services Food and Drug Administration Center for Drug Evaluation and Research (CDER) Pharmaceutical; 2020. Available online: https://www.fda.gov/media/136289/download

[89] Jing JLJ, Yi TP, Bose RJC, Mccarthy JR, Tharmalingam N, Madheswaran T. Hand sanitizers : a review on formulation aspects, adverse effects, and regulations. Int $\mathrm{J}$ Environ Res Public Heal Rev 2020;17. https://doi.org/10.3390/ijerph17093326.

[90] Chan APL, Chan TYK. Methanol as an unlisted ingredient in supposedly alcohol-based hand rub can pose serious health risk. Int J Environ Res Public Health 2018;15:6-11. https://doi.org/10.3390/ijerph15071440.

[91] FDA. Safely Using Hand Sanitizer. U.S.: 2021. Available online: https://www.fda.gov/consumers/consumer-updates/safely-using-hand-sanitizer (Accessed on 29 April 2021)

[92] Madhav H, Singh N, Jaiswar G. Thermoset, bioactive, metal-polymer composites for medical applications. Elsevier Inc.; 2019. https://doi.org/10.1016/B978-0-12-8168745.00004-9.

[93] Schanze KS, Shelton AH. Functional polyelectrolytes. Langmuir 2009;25:13698-702. https://doi.org/10.1021/la903785g.

[94] [101] Heilig ML. Polyelectrolyte builders and detergent compositions. 3308067, 1967. Available online: https://patents.google.com/patent/US3308067A/en.

[95] Vleugels LFW, Pollet J, Tuinier R. Polycation-sodium lauryl ether sulfate-type surfactant complexes: influence of ethylene oxide length. J Phys Chem B 2015;119:6338-47. https://doi.org/10.1021/acs.jpcb.5b02043. 
780 [96] English RJ, Laurer JH, Spontak RJ, Khan SA. Hydrophobically modified associative polymer solutions: Rheology and microstructure in the presence of nonionic surfactants. Ind Eng Chem Res 2002;41:6425-35. https://doi.org/10.1021/ie020409s.

[97] Zdziennicka A, Krawczyk J, Szymczyk K, Jańczuk B. Macroscopic and microscopic properties of some surfactants and biosurfactants. Int J Mol Sci 2018;19. https://doi.org/10.3390/ijms19071934.

[98] Som I, Bhatia K, Yasir M. Status of surfactants as penetration enhancers in transdermal drug delivery. J Pharm Bioallied Sci 2012;4:2-9. https://doi.org/10.4103/09757406.92724.

[99] Trabaris M, Laskin JD, Weisel CP. Effects of temperature, surfactants and skin location on the dermal penetration of haloacetonitriles and chloral hydrate. J Expo Sci Environ Epidemiol 2012;22:393-7. https://doi.org/10.1038/jes.2012.19.

[100] Schaefer H, Schalla W, Zesch A, Stüttgen G. Skin Permeability. Springer; 1982. 